\title{
'It's not going to be suburban, it's going to be all urban': Assembling Post-Suburbia in the Toronto and Chicago Regions ${ }^{1}$
}

\author{
Roger Keil
}

Faculty of Environmental Sciences, York University, Toronto rkeil@yorku.ca

Jean-Paul D. Addie

Department of Geography, University College London, London j.addie@ucl.ac.uk

Paper prepared for the International Journal of Urban and Regional Research

March 2015

\footnotetext{
${ }^{1}$ This paper was first presented at a workshop on Explaining metropolitan transformations: Politics, functions, symbols at the University of Amsterdam in January 2013, organized by Willem Salet and Sebastian Dembski. We have benefitted from their comments and those of other workshop participants. Research for this paper was funded in part by the Social Sciences and Humanities Research Council of Canada and the Government of Ontario's Ministry of Training, Colleges and Universities. We wish to thank Julie-Ann Boudreau and the IJURR reviewers for their comments and suggestions. All errors and omissions remain the responsibility of the authors.
} 


\section{'It's not going to be suburban, it's going to be all urban': Assembling Post-Suburbia in the Toronto and Chicago Regions}

Abstract: Urban and suburban politics are increasingly intertwined in regions that aspire to be global. Powerful actors in the Chicago and Toronto regions have mobilized regional space to brand rescaled images of the urban experience but questions remain as to who constructs and who can access the benefits of these revised spatial identities. Local political interests have tended to be obfuscated in the regional milieu, most problematically in the spaces between the gentrified inner cities, privileged growth nodes, and the glamorized suburban subdivisions and exurban spaces beyond the city limits. This paper analyzes how socio-spatial changes in postsuburbanizing urban fringes contribute to how regions are being reconfigured and reimagined. Guided by current debates at the intersection of assemblage theory and critical urban political economy, our analysis demonstrates how socio-technical infrastructures, policy mobilities, and political economic relations are spatially aligned, sustained, and dissolved in splintering North American agglomerations. Particular attention is paid to issues of urban transportation and connectivity in uncovering multifaceted modes of suburbanism that now underlie the monistic imagery of the globalized region. Emergent regionalized topologies and territoriality blur conventional understandings of city-suburban dichotomies in extended urban areas that are now characterized by polycentric post-suburban constellations. In terms of their substance and functionality, 'real existing' regions are currently re-territorialized as complex assemblages that are embedded in a neoliberalizing political economy whose politics and identities are only beginning to be revealed. 


\section{Regions and the Challenge of Global Suburbanization}

Urban peripheries are emerging as key spaces where relational interconnectivities take hold to redefine metropolitan place and globalized space in equal measure. In this situation, urban and suburban politics are not easily separated (Young and Keil, 2014). Yet while the city-region may be "the principal scale at which people experience lived reality" (Storper, 2013: 4), its suburban dimensions have tended to be subsumed within ideational (pre-dominantly center-oriented) constructs of 'the region'. In Toronto, for instance, Richard Florida (2012) recently called for cities and suburbs "to act in harmony as one region" lest the region lose its competitive edge. Such neoliberal regionalization strategies tend to leverage post-political rhetoric that depoliticizes or displaces local tensions by appealing to normative claims of economic competitiveness, resilience, and "quality of life" (Deas, 2014; Haughton et al., 2013; Jonas and Ward, 2007). Processes of symbolization are crucial to reimagining the identity and politics of suburbanizing regions (Dembski, 2015). But since regional image building serves to obfuscate socio-spatial differentiation - especially in the ubiquitous suburban spaces between the hyper-valorized central city, exurbs, and ascendant regional hubs - questions persist as to who constructs, and who can access the benefits of, these revised spatial identities (see Paasi, 2010).

Peck (2011: 896) reminds us that the neoliberal order and the suburban spatial imaginary have had common roots. The combination of neoliberalization and suburban polity has since been even more pronounced in the exopolitan belts of major North American urban centres. After the latest round of crisis-induced urban restructuring, its overall spatialized governmentality has crystallized in "Metroburbia". Here, degenerate bourgeois utopias and a politics of privatism have created a vulgar imaginary reflective and productive of continuities beyond the political economy of crisis that has determined the suburban identity since 2008 (Knox, 2008).

Suburbia, in this sense, is “neoliberalism’s back yard” (Peck, 2011: 892). But just like 'actually existing' neoliberalism, 'the suburbs' are locally contingent, contradictory, and contested 
socio-spatial landscapes. As urban peripheries undergo rapid change, suburbanization - as a linear process of urban extension from a real or imagined center - is challenged by an increasing proliferation of qualitatively distinct suburban ways of life (Keil, 2013); the "disjunct fragments" of Lefebvre's exploding "urban revolution" (2003: 14). Multifaceted modes of suburbanism and the rise of new modalities of (sub)urban governance across the globe now negate monistic interpretations of the globalizing region, and the reification of urban-versus-suburban identities, properties, or politics (Hamel and Keil, 2015; Walks, 2013: 1480). Students of suburbanization have thus begun to speak of suburbs differently and to identify a phase of post-suburbanization as characteristic of today's peripheral developments (Phelps and Wu, 2011; Salet et al., 2014). We use this emerging yet surely transitory concept to distinguish current suburbanizing regionalization from previous phases of peripheral expansion and territorial regulation.

Through this article, we read post-suburbanization in the Toronto and Chicago regions against current debates at the intersection of assemblage theory and critical urban political economy in order to unpack the complexity of post-suburban transformations and their emergent spatial politics. Our analysis focuses on the crucial issues of regional transportation provision, governance, and land use to: (1) demonstrate how suburban municipal and nongovernmental actors play the game of regional image building and inter-locality competition in a globalized context; (2) account for a new post-suburban politics beyond the formal and institutional logics that have traditionally marginalized vast suburban swaths of the metropolis; and consequently (3) establish the post-suburbanizing region as a field of tension between scales, networks, mobilities and ways of urban habitation.

We find the cases of Toronto and Chicago and their comparison notably instructive. Toronto, despite a legacy of largely effective regional government, now finds its extant territorial fixes straining against the implosion/explosion tendencies (Lefebvre 2003) of the post-suburban region. Comparably Chicago, once the paragon of center-oriented urbanism, is struggling to accommodate polycentric imperatives into its regionalized growth and governance dynamics. As 
major North American global city-regions, they present diverse strategic mechanisms and contexts for regionalization and post-suburbanization in broadly similar geopolitical settings. ${ }^{2}$ In contrast to smaller, more centralized states where regionalism has been more of a top down process, ${ }^{3}$ the relative power of local interests in larger, more federalized countries such as Canada and the United States has led regionalism to be driven, oftentimes, by bottom-up imperatives (Cox, 2010; Harding, 2007). In analyzing the emergent constellations in the Toronto and Chicago regions, we are well aware of, and are building on, seminal work on regional urbanization and polycentric development drawn from cities in North America and beyond. ${ }^{4}$ Classic contributions on regionalization during the post-Fordist transition coincided with studies on the changing nature of urbanization and suburbanization to provide a revisionist view of cities and suburbs (Fishman, 1987; Lewis, 2004; Teaford, 1997). While specific lessons are difficult to draw from this literature, it has opened a necessary awareness that processes of suburbanization, or of the creation of "exopolis" (as Soja may have had it), are not a perennially subordinated affair. Rather they are now written into the code of globalized urbanization everywhere (see Hamel and Keil, 2015). The study of urban regions no longer necessarily starts from the centre to ripple out in concentric rings into an allegedly undefined (or agricultural) hinterland. There are clearly important oscillating growth dynamics and feedback relationships between centre and periphery that have to be seen as constitutive to all urban and theorizing today.

The paper is organized as follows. We begin by conceptually situating our argument in relation to on-going debates on the spatiality of urban and regional politics before establishing

\footnotetext{
2 The Toronto and Chicago regions present different territorial arrangements and political cultures. The City of Toronto sits at the centre of an extended urban region organized into four municipal-regions (containing a total of 24 municipalities) under a powerful province government. The Chicago region is characterized by high levels of political fragmentation and houses nearly 1,300 units of local governments (including 267 municipalities and 587 special purpose bodies) with significant degrees of home rule authority.

3 This has been most notable in the United Kingdom, which has provided an empirical lens for innovative and influential relational interpretations of regional politics by scholars including Allen, Cochrane, and Massey.

${ }^{4}$ The New York region has captured much of the attention due to its extensive history of regionalization. More recently, Los Angeles's exurban constellation has been deemed to display a paradigmatic array of "postmodern" spatial characteristics (Soja, 2000). In Canada, much work has been published on Vancouver as a model for regionalism. Toronto and Montreal have also been subject to studies examining how state spatial strategies mobilized the urban region as a tool to deal with crisis-induced restructuring (Boudreau et al., 2007; Keil et al., forthcoming).
} 
our approach to analyzing the power relations and spatial specificities of (post-)suburbanizing regions. The remainder of the paper presents an exploratory examination of the production, symbolization, and utilization of transportation in post-suburbia. The comparative analytical approach expands the underlying relations and contingencies of what we elsewhere term 'real existing regionalism' (Addie and Keil, 2015) by: examining the production of new regional imaginaries; unpacking the assemblage and splintering of hard and soft post-suburban infrastructures; and assessing the incipient political practices developing in/from the peripheries of North American regions. The study draws from semi-structured interviews conducted in southern Ontario (19) and northeastern Illinois (18) between 2008 and 2011. Municipal (city and suburban), regional, and provincial/state government officials, economic developers, and urban and transportation planners were interviewed as institutional gatekeepers with key knowledge of development and growth management agendas at multiple scales. Representatives from nonprofits, transit advocacy organizations, and community groups were asked to address their stakeholders' interests regarding regional transportation and politics of urban development. The protocols of these interviews involved a set of exploratory questions that probed the intersections of governance, politics, and transportation planning under conditions of neoliberalization and globalization in both city regions. Our analysis of these interviews isolated competing and coalescing storylines and narratives that are selectively presented in original quotations and paraphrases in the sections below. Discourse analysis of planning documents, reports, community group materials, and newspapers in both regions support the interview data.

\section{Spatializing the Politics of Suburbanizing Regions}

Post-suburbanization is shaped by, at the same time as it remakes, emergent urban regions and must be understood in relation to broader forms of global urbanization (Keil, 2011). Contextualizing variegated suburbanisms within post-colonial and post-metropolitan 
urbanization processes is then a necessary step in critically analyzing the underlying social relations that shape spatial patterns, concrete practices, and political possibilities in suburbanizing regions (see Wills, 2008). In contrast to the classical trajectory of Anglo-American suburbanization, diversity (of populations and economies) and the immigrant experience have come to characterize much of suburban Canada over the past four decades (Fong et al., 2005; Teixeira, 2008). Markham, a city of 300,000 north of Toronto, is now statistically the most diverse community in Canada. Demographic transformations are also evident across Toronto's formerly white, middle-class post-war suburbs, which now have largely non-white and immigrant populations (Hulchanski, 2010). In the United States, where there was once the general idea that poor inner cities are the racialized hole in the wealthy white, middle class donut of the metropolitan ring, there is now recognition of rising poverty in the suburbs (Kneebone, Nadeau, and Berube, 2011). In Chicago's suburban and exurban 'collar counties' (DuPage, Kane, Lake, McHenry, Will and suburban Cook counties), median incomes have declined at a rate notably outpacing jobs losses between 2006 and 2010 (Knowles, 2011) while new patterns of immigration and transnational connectivity reshape the region's social and ethnic geography (Jones-Correa, 2006).

These socio-spatial transformations underpin the emergence of new forms of peripheral development, urban governance, and urban identities. Gone are the times where politics could safely be located along socio-demographic lines as was often assumed in the past. Indeed, jettisoning antiquated urban-suburban conceptual divides has become even more urgent in postfinancial crisis times (Schafran, 2013). In the following, we consider how on-going debates over the topographic (vertical) and topological (horizontal) dimensions of political space can both inform and challenge our understanding of post-suburbanization and the politics and potentialities of suburbanizing regions. 
The game of regional image building and inter-locality competition is currently played over a shifting spatial terrain. Much recent debate on regionalism has focused on the nature of territorial politics underpinning new urban scales of governance. Neoliberal approaches to local economic development have galvanized an apparent conceptual and policy consensus regarding territorial development at the (city-)regional scale (Deas, 2014; Jonas and Ward, 2007; Scott, 2001; Storper, 2013). The traditional political link of regionalization and redistribution has consequently been severed as states pursue "competitive regionalism" (Ward and Jonas, 2004) as part of an overall rescaling and reterritorialization of global capitalism (Brenner, 2002; Jonas, 2011). The problematic of transportation has featured prominently in debates over the restructuring of regional territoriality; both in terms of major infrastructural investments aimed at binding globalization processes to place (Graham and Marvin, 2001; Kirkpatrick and Smith, 2011), and in terms of a "territorial politics of collective provision" that seeks to strategically leverage infrastructure investments to secure social reproduction at the regional scale (Jonas et al., 2014).

The institutionalization of a multilayered and dynamic mosaic of urban governance has invoked new topographical understandings of regional territoriality (Brenner, 2004; Painter, 2010). Established theories of urban politics, however, have struggled to account for both the territorially defined interests/place-based identities and the topological connectivity of globalizing regions. Urban political analyses drawing from regulation and urban regime theories have largely remained preoccupied with bounded constructions of urban regions - organized by established economic and infrastructural connectivity - and have subsequently tended to marginalize the importance of non-local political relations (Phelps and Wood, 2011: 2600). In response, many urban scholars have refuted conceptual frameworks premised upon nested territorial configurations and embraced relational ontologies of flow, translocal connectivity and porosity to more adequately theorize the contemporary metropolis (Amin, 2004; Jones, 2009; Massey, 2005). 
Reflective of this 'relational turn', the concept of assemblage helps negotiate the tensions between regions as territorial constructs - the outcome of political endeavours fixed in space and the generative power geometries that inevitably transcend topographical administrative boundaries (Allen and Cochrane 2007, 2010, 2014; McCann and Ward 2011; Sassen 2006). ${ }^{5}$ Assemblage thinking, although far from a singular, cohesive intellectual program, draws upon notions of emergence, non-linearity, and adaption to destabilize the reification of hegemonic conditions and "establish a foundation of empirical knowledge available to the public for a democratic politics" (Farias, 2011: 371). Because urban power relations are viewed as always imminent and indeterminate, particular assemblages do not express the products of any necessary social relations but rather reflect the co-presence of overlapping differentiated realities in cities constituted by "concrete practices, located in situ" (Farias, 2010: 13). The emergence of more diffuse and fragmented forms of regional governance, so the argument goes, is best analyzed as a 'regional assemblage' of public and private political actors whose power is 'lodged' within the region, and whose spatial reach is not tied to conventional notions of territory (Allen and Cochrane, 2010: 1073). New spaces for agency and political action thus emerge since "urban political formations... are understood not as the structural effect of broader forces but as fluid and performative arrangements and achievements" (McGuirk, 2012: 262).

On the face of it, such topological accounts of state space offer a reasonable means to negotiate regions as vertical hierarchies and horizontal networked configurations. Yet despite considerable conceptual and methodological innovation, the question of what forces shape these concrete practice remains, as does the necessary or contingent role of the city (and the urban) in various assemblage theories' political programs (see Wachsmuth, 2014). The flat ontological underpinnings of much assemblage thinking marginalize, if not outright reject, the presence and

\footnotetext{
5 The theory and language of assemblage has been appropriated in divergent ways in urban studies; from setting the foundations for an alternative ontology of the city (Farias, 2010) and a guiding a methodological orientation (McFarlane, 2011a) to serving as a heuristic to conceptualize global transformations (Sassen, 2006) or the capacities of 'policy mobilities' (McCann and Ward, 2011).
} 
efficacy role of social structures and relations (Cox, 2013: 54). As an open and exploratory inquiry (opposed to critique), 'assemblage urbanism' struggles to explain the social relations that constitute broader urbanization and restructuring processes. Focusing on the ways in which externally related components are assembled, detached from, and inserted into, social and technical systems, critics suggest, profoundly infringes on assemblage theory's capacity to grasp the political and economic challenges of contemporary urbanization (Brenner et al. 2012: 127).

\section{Engaging 'Real Existing Regionalism' through Post-Suburbanization}

We concur that assemblage urbanism does not relieve us of the need for more overarching theorization of structural change. While the spatial specificities of urban politics remain subject to concerted debate in this journal and elsewhere (Rodgers et al., 2014), the shift away from territoriality has evidently led the analytical frameworks and spatial grammar of regional assemblage to downplay the continuing significance of social, political and morphological obduracies in shaping region's internal and external structures and relations. This is acutely evident in the marginal role afforded to suburban transformations across much of the current literature on regional politics and governance. Our aim, therefore, is not to reconcile the diametrically opposed flat and deep ontologies of assemblage thinking and critical political economy. Rather - because neither regional nor post-suburban politics neatly align with accounts of complex, vertically integrated multi-scalar governance or topological readings of horizontal, multi-level politics - we propose selectively leveraging insights and methodological apparatuses from assemblage urbanism to critically engage post-suburban transformations in the Toronto and Chicago regions in two ways.

First, assemblage thinking's analytical orientation offers a novel way to discuss the actual politics of emerging regional governance regimes in the triangle of state, accumulation and privatism (see Ekers et al., 2012). Highlighting topological connectivity, non-local actors, and 
policy mobilities enables the identification of processes of connection and fissure, rather than rendering discrete spaces integrated or bypassed within urban systems (MacLeod, 2011: 2651). In doing so, the notion of assemblage can open spaces for adaptive urban politics attuned to the complexities and political subjectivities of polycentric and globally connected urban regions. Second, assemblage thinking brings to the fore socio-technical systems as a contested site of urban politics. Deploying a sympathetic reading of assemblage urbanism to frame transportation as an empirical research object for political economy analysis provides a means to describe the multiple processes through which capitalism operates and political economy categories are brought into being, held stable and ruptured (McFarlane, 2011b).

The dynamics of 'real existing regionalism' are the contested product of discourses, technologies (material and of power) and territorial relationships (Addie and Keil, 2015). Urban assemblages are constituted in place; they are both territorialized and are generative of new territorialities. Since particular articulations of regionalization spatially express the contradictions of capitalist social relations and the necessary territorialization of capital (Cox, 2013; Harvey, 1978), the core categories of critical political economy (accumulation, class, property, rent, and uneven development) remain central to our analysis. In the following, we reinsert transformations in the metropolitan periphery into regional debates by considering how sociospatial changes in the fringe of urban regions contribute to new strategies of regionalization, symbolization, and political practice. In short, we argue that urban regions are currently reterritorialized as complex socio-technical assemblages that are embedded in and structured by a neoliberalizing political economy. Recognizing the social and infrastructural complexity evident in new post-suburban constellations challenges and redefines understandings of regionalization grounded in both competitive locational advantage (e.g. Brenner, 2004) and collective provision (e.g. Jonas et al., 2014).

The tensions between the normative interventions that characterize many regionalist conversations and the territorial technologies that are deployed to give these strategic direction 
disclose an on-going negotiation of both top-down and bottom-up actions that shape regional development aims (see Harding, 2007: 444). The emergence of plural suburbanisms in an environment that was ostensibly meant for a homogenous and highly localized life tangibly marks a conflict between suburbanization as a process with a particular long-term outcome (built and social environments) and suburbanisms as rapidly diversifying practices of everyday urban life. This, of course, has significant ramifications for our understanding of how regions are produced, experienced, and governed: globalizing suburban regions blur conventional understandings of city-suburban dichotomies and are producing new political divisions and new political identities. Here, the relational and territorial politics of transportation loom large. It is to the politics and urbanism that is forged on and across this terrain that we now turn.

\section{Post-Suburban Political Economy and the Social Cleavages Underlying Regional Assemblage/Splintering in Toronto and Chicago}

Animating New Regional Institutions and Visions

Over the past decade, new ways of talking about and branding regional development have taken hold in the Toronto and Chicago regions. The Government of Ontario actively embraced the role of 'regionalizing state' after the provincial Liberal Party came to power in 2003. The Liberal government's 'Places to Grow' regional growth management framework, alongside a large regional Greenbelt (Macdonald and Keil, 2012) introduced during 2005-2006, attempts to integrate land-use, environmental, and transportation policy in a manner that notably contrasts to previous regional projects in southern Ontario, which hued closely to the redistributive logics of spatial Keynesianism (Boudreau et al., 2007). Places to Grow is premised upon a new territorial concept of the region; one constructed around the spatial imaginary of the 'Greater Golden Horseshoe'. Functionally, this involves the development of a series of growth centres and no- 
growth areas in large contiguous sections of highly developed land. Politically, it relies on new governance mechanisms to marshal the antagonistic political relations between the dense urbanity of the metropolitan core and the sprawling suburbanity that lies beyond.

Transportation infrastructure holds a central position within the Province's development vision. A provincial deputy minister confirmed:

There has been a significant rebuilding of the government's social policy responsibilities beginning with hard assets in the area of healthcare, in particular hospitals, and in other areas as well, justice facilities, for example. But the biggest, even as there's been a lot of attention paid to that, the biggest ministry with regard to infrastructure continues to be transportation (Deputy Minister, Ontario Ministry of Infrastructure, interview, 2011).

The Big Move, a 25-year, $\$ 50$ billion regional transportation plan overseen by a newly formed regional transportation body, Metrolinx, supports Places to Grow. Metrolinx’s (2008) vision of regional mobility recognizes the continued importance of maintaining transportation infrastructure to support a healthy downtown core, but also emphasizes a "need to promote senses of place" through increasing and diversifying employment and housing options across the region (Transportation Policy and Planning Advisor, Metrolinx, interview, 2010). Regional growth management, as such, functions as a state strategy to realize the internal connectivity deemed necessary to support Toronto's economic engine. This is true not just in terms of the movement of people which takes all the attention in public debate but also the higher-scale matters of logistics and good movements, which may be the main driving factor for business elites and political decision-makers in breaking down intra-regional obstacles in the first place (CEO, Toronto Civic Action Alliance, interview, 2011).

Regionalism has also been embraced in Chicago as a means to ensure economic competitiveness and metropolitan resiliency, albeit more openly driven by corporate and civic leaders than governmental rescaling. The new regionalist vision and vigorous lobbying of Chicago Metropolis 2020 (Johnson, 2001) prompted the State of Illinois to institutionally 
consolidate transportation and land-use planning across the seven-county Chicago region under the new Chicago Metropolitan Agency for Planning (CMAP) in 2005. From the outset, CMAP sought to position itself as a consensus-forming institution. Work on CMAP's (2010) first comprehensive plan, Go to 2040, commenced with a program of regional visioning that utilized workshops with key stakeholders and residents and on-line technology-based tools to facilitate public participation. The resultant document articulated a holistic vision for future regional development covering governmental transparency and regional innovation to smart urbanization, regional corridor development, and integrated multimodal transportation.

The regional imaginaries presented in both cases codify policy and planning frameworks intended to curb sprawl and foster polycentric and sustainable urbanization as a response to pressing imperatives of economic competitiveness and regional resilience. It is important to recognize that variations between Canada-Ontario and the United States-Illinois contexts considerably impact each institution's structural capacities. Metrolinx, as a provincial agency, has considerable power to set the transportation agenda in southern Ontario through planning and operating major elements in the regional transportation system. In contrast, although CMAP has legislative authority to produce regional plans, they lack the statutory responsibility to make sure that municipalities prepare a compatible local plan. In the words of a CMAP planner, "that means that they don't have to be in compliance with what we recommend and this is part of the problem" (Community and Economic Development Planner, CMAP, interview, 2009). Transit, commuter rail, and highways/tollways in northeastern Illinois are planned and operated through a fragmented governance regime. Still, the proliferation of regional 'smart growth' agendas across North America reflects a broad movement towards the consolidation of regional growth management functions. The rise of densified growth centers supported by a network of 'mobility hubs' and privileged infrastructure corridors belies an emergent territorial politics now being played out across the spaces of the globalizing region and unfurling post-suburban constellations (see Keil and Young, 2011; Peck, 2011). 
Assembling the Infrastructure of Post-Suburbanization

Taking their cue from Places to Grow, many of Toronto's neighbouring municipalities have embraced planning and policy agendas centred on intensified urbanization. The rapid development of post-suburban growth centers and 'mobility hubs' along Highway 7, including Markham Town Centre, Vaughan Metropolitan Centre and Richmond Hill Town Centre has engendered both a dramatic transformation of the Greater Toronto Area's built environment and those suburban municipalities' spatial imaginaries. The City of Vaughan's 2020 strategic plan (2011: 1) envisions a transition "from a growing suburban municipality to a fully urban space". Vaughan Metropolitan Centre "is not going to be suburban; it's going to be all urban" (Projects and Public Relations Coordinator, York Region Transit, interview, 2010) (see Figure 1). These urbanizing discourses are explicitly tied to ideas of built form and function. They constitute elements of an alternative regional development model and spatial imaginary gravitating around a central suburban axis (opposed to established corridors in the city of Toronto) that challenges the territorial centrality of the urban core, the political primacy of the City of Toronto, and conceptions of urbanism abstracted from the pre-war city.

\section{[FIGURE 1 HERE]}

Transit infrastructure vitally supports this urbanizing agenda. In on-going debates on regional transit development, suburban municipalities are increasingly demonstrating an urban and regional vision more advanced (and more aligned with the province's spatial strategies) than the City of Toronto (Drennan, 2013). With accelerating suburban growth in areas lacking transit infrastructure, interviewees demonstrated a mounting recognition that mass transit service can neither stop at municipal boundaries, nor concentrate on moving people downtown. This issue 
though, does not simply rest on service integration or the introduction of inter-jurisdictional routes but in the establishment of common visions, practices, and political synergies. Metrolinx has consequently devoted substantial attention to fostering the municipal and public-private partnerships deemed necessary to realize trans-jurisdictional high-order transit corridors. A senior Metrolinx official suggested: "this is now a city-region... The city of Toronto is still very important, the city of Mississauga is still very important, but the line on the map is very blurry now. One city really blends in to another" (Executive Vice-President, Metrolinx, interview, 2010). Infrastructural connectivity is seen as defying established frameworks of hierarchical political territoriality while fostering new topological patterns of polycentric connectivity across regional space.

The assemblage of social, technological, and governance elements supporting the introduction of bus rapid transit (BRT) along major suburban arterial routes in York Region (and later Peel Region) reveals a post-suburbanizing spatial politics grounded in such topological connectivity, but one that also shapes, and is shaped by, distinct mechanisms of territorialization. Post-suburban transit beyond the city of Toronto remains largely conditioned by individual municipal regions. The consolidation of five local bus services into York Region Transit (YRT) in 2001 and subsequent system restructuring precipitated by the York Consortium (a group of private sector firms specializing in developing transit systems) laid the groundwork for a steep increase in bus service and an annual ridership. Four years later, the Regional Municipality of York and York Consortium established the Viva BRT network via a public-private partnership (see Figure 2). York Region maintains ownership of assets and sets fare and services levels with system operations have been outsourced to French multinational Veolia, in cooperation with local transportation company Tokmakjian Inc. This governance arrangement has allowed bus transit policies and expertise - honed from Bogota to Bordeaux and Phoenix - to be imported into to the medium-size suburban towns north of Toronto while opening novel financing 
mechanisms. Yet it also supports a local development regime that purposefully seeks to enable and capture investment in the built environment. As a Viva representative explained:

The [public-private partnership] allows us to do transit-oriented development. We've not actually done it, but it does allow us to build above our stations. The Region can't own an asset or make money on an asset, but we have the ability to be, not developers, but

certainly, we can handle our assets differently than a [Municipal-]Region can. That's where some of the standalone corporation thinking comes in as we are developing big stations and big terminals. We may build the basement, but it allows us to sell the air rights, so it trades off the economic investment into the transit (Projects and Public Relations Coordinator, York Region Transit, interview, 2010).

YRT and York Consortium have placed concerted attention to cultivating a high-end transit experience to address the cultural stigma associated with local bus service in North America. Their aim is "to reach the people, the business people, who are not going to look at riding transit as a step down. We've tried hard to put a distinguished, upscale, comfortable vehicle on the road" (ibid). Viva initially operated express bus service in mixed-traffic but in 2009, the VivaNext project began the process of constructing dedicated bus-only 'rapidways' and 'vivastations' in the centre of York Region's key arterial routes to ensure the free flow of express services (see Figure 1). Consequently, BRT has engendered bypassing effects that have extended both technical and cultural distinction as a core element of post-suburbanization.

\section{[FIGURE 2 HERE]}

In northeastern Illinois, CMAP's advocacy of smart growth concentrated on key regional hubs won support from edge cities seeking to position themselves as growth centres. Suburban municipal and county officials interviewed at the height of the 2008-2009 Financial Crisis (and its associated spike in gas prices) recognized the importance of integrating transit and land-use 
decision-making. Supported by consistent ridership growth through the 2000s, Metra commuter rail stations have emerged as focal points for transit-oriented development and targeted investment aimed at revitalizing suburban downtowns (Schwieterman et al., 2012). However, Metra's fixed hub-and-spoke infrastructure ties transit-oriented development to downtown Chicago's economy, even as its share of regional employment has declined. The lack of effective, efficient transit within and between Chicago's social and economically diversifying collar counties has continued to exacerbate the spatial mismatch between regional housing and employment opportunities (Center for Neighborhood Technology, 2012). Infrastructural and commuting obduracies have consequently contributed to a regional polity that ties the suburbs and the suburban imaginary to the city in a necessary, but often antagonistic, relationship.

Originally announced in 2003, Metra's STAR Line has emerged as a popular proposal to integrate regional space and open inter-suburban transit. The plan aims to connect major regional employment centres by implementing circumferential commuter rail service from Joliet, Aurora and Elgin to O'Hare Airport via the Elgin, Joliet and Eastern Railroad (EJ\&E) right-of-way (see Figure 3). Suburban officials interviewed for this study welcomed the STAR Line concept as an important step in establishing regional hubs, although several expressed concern over the Line's ridership potential and ability to attract commuters. The project of regionalization presented by the STAR Line, however, has come into conflict with the circulation of capital and goods operating at alternate scales. The EJ\&E railroad forms part of a continental rail infrastructure centred on Chicago. Its purchase by the Canadian National Railroad (CN) in 2009 exposed inherent tensions between the practices and imaginaries of Chicago as a regionalized global port - a central logistics node in international trade and capital flows - and a space of multiple, territorialized social identities and interests (Cidell, 2011). The contradictory logics of regionalism as a territorial politics of collective provision (i.e. the internal circulation of urban inhabitants) and a project of competitive territoriality (both fostered top-down) have been internalized within 55-miles of suburban rail infrastructure. Reflecting this, debates over the use of the EJ\&E line re- 
opened enduring tensions between Chicago and the collar counties. Suburbs that strongly backed rail restructuring in Chicago were left frustrated, as the City did not repay their support by actively opposing the $\mathrm{CN}$ purchase and its associated increases in suburban freight rail traffic.

\section{[FIGURE 3 HERE]}

Initiating the STAR Line as a BRT system, an idea advocated by CMAP and the Center for Neighborhood Technology, offers a potential means to mitigate conflicting local and global demand on the EJ\&E right-of-way while testing potential ridership on adjacent roadways. Such thinking has been explicitly influenced by the successes of Viva (among other systems). BRT is receiving an increased level of interest as a sustainable transit technology across Chicago's regional transportation and planning communities (see Metropolitan Planning Council, 2011). Go to 2040 includes proposals for several modes of BRT, but these plans, and those forwarded by many suburban officials (with the exception of DuPage County's J-Line) have focused on individual routes deploying differing designs and aesthetics, rather than comprehensive systems comparable to those being rolled-out in southern Ontario. Such piecemeal proposals - indicative of the Chicago region's localized politics and fragmented governance regimes - are unlikely to significantly address the negative perception of bus service in Chicago's collar counties (and wider stigma of mass transit prevalent in the United States). Metra has cultural cache and strong market share but ridership trends on Pace, northeastern Illinois' suburban bus system, do not indicate demand for increased bus service (Regional Transportation Authority, 2012). As a collar county official put it: "It won't work until we can demonstrate that... it can really make a change in getting people where they need to go in less time... I just recently saw [the system] in Bogota and it is unbelievable how the cars stack up while the BRT just hums along. That's the picture we've got to draw here" (County Representative, DuPage County, interview, 2008). The case of Viva indicates its success likely hinges on: (1) long-term process pushing people to alternative 
transportation modes (e.g. as a consequence of rising gas prices); (2) cultivating the ability to exploit the cultural distinction between high-end express service focused on the logics of global regionalism and local routes that structure everyday life for many transit-reliant residents; and (3) developing institutional mechanisms and symbolism that can connect and reconfigure disparate auto-dependent suburbs.

Negotiating Splintering, Persistent Territorialized Logics, and Social Obduracies

BRT may help integrate regional space but the necessary splintering of local and express routes privileges particular journey types, riders and regional rhythms of mobility. Dispersed, decentralized industrial, commercial, and institutional regional centres with access still predominantly premised upon automobility create lengthy commutes in terms of time and distance. Although the province of Ontario's GO Transit bus and rail network (now operated by Metrolinx) currently enables people to readily commute to the urban core from the exurbs, the regional transportation system provides few competitive alternatives for mobility outside of the private car for residents in both mature inner and burgeoning outer suburbs (Ipsos Reid, 2012). Relative spatial distantiation across Toronto's urban periphery has been notably problematic for recent immigrants and those dependent on public transit (Axisa et al., 2012; Turcotte, 2011). This is especially prevalent in Toronto's inner suburbs where growing social diversity has coincided with the suburbanization of societal problems long thought of as belonging to the inner city. Terms like the 'racialization of poverty' and 'vertical poverty' have become strongly associated with the extensive suburban tower neighbourhoods where the combination of immigration, renter status, gender dynamics, and 'visible minority' membership has become a predictor of structural poverty (United Way Toronto, 2011). While there are still considerable spaces of poverty downtown, most of the city's 13 'priority neighbourhoods' (where the municipality sought to apply place-based policies for neighbourhood amelioration) are located in under- 
serviced, ethnically diverse districts in the far corners of the city. The neighbourhoods of Jane and Finch, Kingston Galloway and Malvern have become household names; both as markers of 'Othered' urbanity and objects of perhaps misguided 'fast policy' to pump resources into places that are considered breeding grounds of poverty, educational failure, and crime.

The suburbanization of poverty and socio-economic decline, though, does not stop at Toronto's city boundaries. The concept of 'priority neighbourhoods' has now been exported to allegedly wealthy suburbs that have begun to show growing social distress but have been slow in building the kind of social service and technical infrastructure one associates with inner city areas (Lo, 2011). Geographical distance between rich and poor may collapse within post-suburbia, but relative connectivity and the symbolic distance between centre and periphery are greatly exacerbated. This is clearly evident across Steeles Avenue, the boundary between the city of Toronto and York Region (see Figure 2). Here, alternative transportation politics, divergent built environments, and differing perceptions of mass transit territorialize competing mobility patterns. The availability of free parking in Vaughan is a significant attraction for automobile commuters and supports a pro-development suburban political agenda, while transit riders moving between Toronto and York Region are required to pay two fares when crossing Steeles Avenue or transferring between the Toronto Transit Commission (TTC) and YRT/Viva systems.

The protracted challenge of extending the TTC's Spadina and Yonge Street subways into York Region proves bridging such divides is a complex issue that requires local governments and transit agencies to reassess established planning philosophies and practices. The TTC was initially reluctant to extend the Yonge Subway beyond its present terminus at Finch Station, fearing increased numbers of suburban commuters travelling into the urban core on already crowded rush hours trains. At the same time, the then Chair of the TTC argued that residential and employment densities north of the city - even surrounding the Province's growth hubs - were not inductive to the reverse commute ridership levels necessary to justify the expansion of heavy rapid transit line infrastructure beyond Toronto (Chair, Toronto Transit Commission, interview, 
2010). By contrast, York Region sees the continuing shift of economic activity and population growth in the outer suburbs would prompt ridership increases in both directions (Projects and Public Relations Coordinator, York Region Transit, interview, 2010). The politics of subway extension remain contested, but the imperatives of the Places to Grow framework have compelled cooperation despite divergent institutional practices and understandings of regional development. The 8.6 mile, six stop Spadina extension, has brought city and suburban actors together, with the TTC leading tunnel construction and York Region serving as the service manager responsible for coordinating development as subway stations reach the surface.

As in southern Ontario, the institutional and social dimensions of post-suburbanization in northeastern Illinois invoke on-going contestation and negotiation surrounding enduring social and territorial obduracies. Yet in contrast, municipal fragmentation and strong home rule powers have ossified a politics driven by local property and taxpayer rights. Whereas Metrolinx is empowered to exercise significant influence over transportation planning across the Toronto region, CMAP has limited capacity to direct transportation and land-use planning in the city of Chicago. Moreover, the Agency also faces a deep scepticism amongst government officials in the collar counties arising from a perceived centre-oriented approach to regional space. For one collar county transportation planner, the proposed infrastructures guiding CMAP's growth management strategies are unlikely to rein in establish modes of peripheral expansion:

[CMAP] lacks relevance... because it is not addressing the reality of what happens with the property market [in the outer collar counties]. There's a tendency to just want to have new urbanism happening everywhere else and keep the agricultural stuff green. If it hasn't happened in the last 60 years, it isn't going to happen now because somebody has good intentions and a plan. The reality is that people are making tons of money converting agricultural lands to other uses; there's no surer way of making money in this area (Planner, Department of Transportation, McHenry County, interview, 2008). 
As a result, the challenges presented by Chicago's regional development are predominantly addressed by overlooking the morphologically integrated but institutionally differentiated suburbs in favour of localized solutions.

Over the past three decades, the shifting distribution of economic activity and geography of transit restructuring have hit African-American communities on Chicago's West Side, South Side and near south suburbs particularly hard. These areas contain a large supply of affordable housing but accommodation-based household savings are largely offset by increased costs of transportation. The rationalization of Chicago's elevated (El) rail system during the mid-1990s (including route realignment and station closing in the city's marginalized south side) sparked community protests and accusations of racism on the part of the City and Chicago Transit Authority (Washington, 1994). These complaints were summarily dismissed as those of a "few holdouts... made so marginal by the new inclusive style of Chicago governance [under Mayor Richard M. Daley] that [they] barely registered" (Longworth, 2004: 83), but community resentment resurfaced as the Chicago Transit Authority reconfigured El service on the city's west side in the mid-2000s. In order to facilitate the doubling of service on the express service Congress El, trains on the Douglas Branch were rerouted through downtown via the Paulina Connector and Lake Street El, instead of running through the Dearborn Subway to O'Hare Airport as they had since 1958. The changes benefited commuters from near Western suburbs who were travelling downtown at the expense of residents served by the local service on the Douglas Branch. Local community organizations unsuccessfully opposed the realignment, arguing against the loss of access to employment hubs at the University of Illinois-Chicago and the Illinois Medical District, as well as the increased commuting time for workers travelling to blue-collar jobs around O’Hare Airport (Community Organizer, Little Village Environmental Justice Organization, interview, 2009). The resultant restructuring cleaved low-income, racialized communities from access to privileged transit routes while suburban and global commuters realized improved connectivity to prioritized centers of regional accumulation. 
Fixed capital embedded in mass transit systems exacerbates the difficulties in developing infrastructures and service for the polycentric regions. Moreover, current social transformations in Chicago's urban periphery at once exhibit increased levels of ethnic diversity while continuing to the shaped by legacies of economic and racial segregation. Census data indicates AfricanAmericans are leaving the city for the suburbs; a trend accelerated by the foreclosure crisis' impact on largely Black south and west side communities. These demographic shifts are significantly uneven. The south suburbs continue to provide housing options for middle class African-American homebuyers, but escalating housing prices in the early twenty-first century fostered their displacement from affluent Chicago suburbs like Geneva, Glencoe and Glenview (Rodkin, 2011). In addition, whereas new immigrants traditionally settled in the inner city and moved to the suburbs as their economic situation permitted, newcomers to Chicago now tend to bypass established gateway districts and move directly to the suburbs. This trend is most pronounced for the region's Latino population who are increasingly bypassing established portof-entry neighbourhoods in favour of Chicago's satellite cities.

New Regional Imaginaries, Identities, and Politics

Against this backdrop, emergent transnational assemblages of post-suburban politics begin to vex the regional polity in diverse ways that reflect transformations underway in the social and spatial structures of global regionalism. The rise to power of suburban-based regimes (regionally and even federally) in Canada over the past two decades has shifted the meaning of metropolitan politics towards a policy environment of inter-municipal competition. Sometimes, this leads to the intrusion of 'suburban' (i.e. conservative) political values into the usually more progressive urban political realm. Yet suburban regimes in communities around Toronto are also developing a decidedly autonomous set of strategies to make their mark in an increasingly competitive global city environment. 
Here, the post-suburban polity is politically reassembled at all institutional state scales. Territorially, this has been expressed by ethnically diverse and multigenerational organizations that have effectively challenged traditional development driven suburban political agendas (see Citizens Environmental Coalition, 2012). Topologically, the interests assembled in the neoliberal political economy in southern Ontario have struck a chord that resonated well beyond the normal confines of suburban politics. Veolia, and by extension the global governance network supporting post-suburban transit in York Region, has been central here on two accounts. First, labour relations have been affected by new socio-technical and political economic regimes. Drivers for Viva are paid considerably less than their regional counterparts in other jurisdictions and Veolia has been criticized for poor labour relations and working conditions (Amalgamated Transit Union Local 113, 2008). Disputes over pay prompted strike action between 24 October 2011 and 24 January 2012 that impacted 60 percent of service in York Region. Second, in the spring of 2011, Veolia's contracts to provide services to commuters and to transport waste from illegal settlements on the West Bank disrupted traditional staid developmental politics in Markham. As Peto (2011) details, the heightened politics surrounding a City Council debate to ban Israeli Apartheid Week from the municipality was partially influenced by debates at nearby York University where such politics were more naturally at home. Yet the emergence of a new type of suburban reality in which governance was retooled politics - focused by the infrastructural assemblage of post-suburbanization - disclosed the remarkable degree of entanglement with networks of global political economies, immigration, and corporate strategies that now position the urban periphery at the centre of global regionalization.

In Chicago, the entanglements of multiscalar politics and social interests have been clearly evident (in a different form) after CN's purchase of EJ\&E Railroad. CN has pursued an aggressive policy of system expansion in order to position the railroad within a continental, rather than nation, economic system following the advent of North American free trade. Acquiring the majority of the EJ\&E Railroad not only allowed $\mathrm{CN}$ to bypass congested tracks in central 
Chicago but also connected their expansive Canadian network - including tracks to the oil-rich Alberta Tar Sands - to American holdings that extend to the Gulf of Mexico. The Chicago region would consequently be positioned at the centre of a major transcontinental economic artery. Affluent north and western communities expressed concerns surrounding noise and air pollution, delays at at-grade crossings caused by increased rail traffic, and the elevation of freight rail movement over regional commuter lines, while others debated the potential economic benefit the deal would have for the region (also see Cidell, 2012). The EJ\&E purchase posed a more complex question for the south suburbs. The sale allowed $\mathrm{CN}$ to relocate their switching operations to Indiana and look to convert their Gateway Yard in south-suburban Harvey to an expanded intermodal facility, presenting a potential economic boon for a low-income, economically depressed, and predominantly Black area of the Chicago region. Yet increased freight movement still poses significant disruption for local residents and consequently support for the $\mathrm{CN}$ takeover was divided based on parochial interests.

The particular assemblage of global infrastructure, existing (yet underutilized) industrial capacity, and the need for innovative, localized economic development, however, has forged an emerging political consensus surrounding a post-suburban economic development agenda. The South Suburban Mayors and Managers Association, in collaboration with a network of regional partners, is at the forefront of a redevelopment strategy aiming to reimagine Chicago's industrial south suburbs as a modern sustainable manufacturing cluster for green infrastructure. Their revitalization strategy and sustainability plan is premised on integrating transit and cargo-oriented development with green manufacturing and has received $\$ 2.3$ million in federal funding from the U.S. Department of Housing and Urban Development and Department of Transportation (Center for Neighborhood Technology, 2010). The Chicago Southland ‘Green TIME Zone' and constituent 'Logistics Park Calumet' initiatives present a novel economic development strategy focused on leveraging the social and spatial infrastructure of post-suburbia in Chicago's south but also seeks to mobilize global capital to translate existing brownfield space into desirable housing, 
employment and environmental options (see Figure 3). The intended outcome would reposition the south suburbs, both economically and discursively by bundling an assemblage of a sociotechnical infrastructure and a multiscalar political regime into an alternatively territorialized local accumulation regime.

\section{CONCLUSION}

This paper has analyzed the socio-spatial and infrastructural transformation evident in the urban peripheries of the Toronto and Chicago regions to identify the emerging dynamics and spatiality of urban politics in an era of global regionalization. A central task at hand has been to engage and identify the political actors and the spatial imaginaries they have mobilized within suburbanizing North American regions in order to empirically demonstrate and conceptualize the links between urban politics, regionalism, and neoliberal state spatiality they develop. To accomplish this end, we selectively leveraged the analytical orientation of assemblage thinking - namely sensitivity to non-local political agency and an empirical focus on socio-technical infrastructures - to inform a political economy analysis of regional development. Rather than attempting to harmonize the intellectually incompatible positions of (structuralist) political economy and (post-structural) assemblage theory, we utilized the analytical facilities of the latter selectively and surgically in an overall framework set by theoretical loyalties to the former. We are aware, of course, that this strategy also revealed important imprecisions in the political economy framework that can in future be better addressed.

Our analysis has demonstrated, firstly, that the changing context and mechanisms of post-suburbanization are vital elements within the overarching processes of global regionalization. The conceptual frame of post-suburbanization is vital in "[validating] both the overlooked spaces in-between and the emerging metropolitan spaces of which they are part" (Young and Keil, 2014: 1605). Regional space and spaces of spatiality of regionalized urban 
politics are constituted, and assembled, through heterogeneous territorial and topological relations. Differing experiences of regional development and socio-spatial transformations in each region's urban peripheries disclose new articulations of uneven development, global connectivity (transnational linkages and policy mobilities) and social marginalization (via sociospatial polarization and infrastructure bypassing). In this context, we have attempted to address, for example, the continuing association of poverty with the spatial imaginary of the city by shining a light on social marginalization that is often hidden in many suburban spaces. Secondly, selectively applying assemblage thinking to the neoliberal political economy foregrounded the relationships between formal institutional and infrastructural mechanisms restructuring regional development and the politics of everyday spatial practice within 'real existing regionalism'. The global character of regional relationality is now the assumed instrumental rationale of regional development. However, the structured coherence embodied in 'real existing' regions is a product of a diverse set of social relations, territorial strategies and technological solutions deployed by actors with varying structural capacities. This is the terrain on which regional urbanization, and its emergent spatial politics, takes place. The material reconstruction of regions is tied to their symbolic reconstruction in inseparable ways, but this symbolization itself expresses on-going processes of social contestation grounded in and shaped by materially divided interests. We have strongly advocated for an acceptance of the existence and dynamism of a vast variety and multiplied cleavages in suburban identities; both in political and planning practice and urban theory (Savini, 2014).

The mobilization of regional space has the potential to realize progressive societal benefits, as demonstrated in the regeneration imperatives supporting the 'Green TIME Zone' in southern Chicago. But it remains to be seen how these new spatial strategies can effectively marshal the levers of post-suburban regionalism without being coopted by established institutional strategies and elite interests. The (post-)suburban re/insurgence in regional politics is not settled. It is indeed possible that we experience a hardening of lines between inner city and 
more exurban political coalitions. The lines drawn in the political sandbox of metropolitan Toronto are not insignificant and expressive of continued material and ideological cleavages that mar the urban region. The persistence of territorial fragmentation is even more pertinent in Chicago. As with the United States more generally, metropolitan suburbanization ironically established the conditions for a secessionist suburban politics (Peck, 2011). Comparably, the rollout of regionalizing policy agendas tailored to the interests of downtown urban elites (such as those sponsoring the Chicago Metropolis project) may be read, in part, as an attempt to reinforce the city's position relative to debates of regionalism and the potential intrusion of suburban political influence into 'urban' affairs. Still, we see evidence in both the Toronto and Chicago regions that the conservationist, middle-class cultural logics that have underpinned normative readings of suburban politics are now confronted by an incipient post-suburban polity forged through a dynamic and unpredictable mix of cultural identity politics, pro-growth development politics, and socio-economic polarization. These new social and material constellations internalize a contradictory regional politics - one held between the bounded territoriality of institutional structures and the unbounded nature of globalizing urbanity - which fundamentally challenges how suburbanizing regions are governed, and how they are seen by the scholars studying them..

Topological constructions present regions as territorially discontinuous as notions of propinquity - codified through relational networks - incorporate more distant places into regional space. However, if the region is a node of assembled networks, infrastructures, and power geometries, such 'regional assemblages' are not bundled haphazardly in a singular, distinct centrality. Rather, they express polycentric and multiscalar instances of territorial centralization and decentralization. They polycentric suburbanizing region now rises, with its social and spatial structures conditioned by both burgeoning diversity in the metropolitan periphery and the territorializing logics of a global urbanization-as-accumulation. Globalized market discipline, planning policies by regionalizing state apparatus, and urban transportation strategies set the stage for and are defined by idiosyncratic, yet supra-territorially constituted politics. Localized interests 
persist but they are rarely just of the terrain from which they are postulated. They represent topologies of meaning and identity that transcend both the locality where they emerge and the political region for which they seek application. 


\section{References:}

Addie, J.-P. D. and R. Keil (2015) Real existing regionalism: The region between talk, territory and technolgy. International Journal of Urban and Regional Research, 39.2, 407-417.

Allen, J. and A. Cochrane (2007) Beyond the territorial fix: Regional assemblages, politics and power. Regional Studies, 41.9, 1161-75.

Allen, J. and A. Cochrane (2010) Assemblages of state power: Topological shifts in the organization of government and politics. Antipode, 42.5, 1071-89.

Allen, J. and A. Cochrane (2014) The urban unbound: London's politics and the 2012 Olympics. International Journal of Urban and Regional Research, 38.5, 1609-1624.

Amalgamated Transit Union Local 113 (2008) Veolia workers vote to end Viva bus strike in York Region. (available at http://wemovetoronto.ca/?p=502; last accessed 3 November 2011).

Amin, A (2004) Regions unbound: Towards a new politics of place. Geografiska Annaler B, 86.1, 33-44.

Axisa, J. J., K. B. Newbold and D. M. Scott (2012) Migration, urban growth and commuting distance in Toronto's commuter shed. Area, 44.3, 344-55.

Boudreau, J.-A., P. Hamel, B. Jouve and R. Keil (2007) New state spaces in Canada: Metropolitanization in Montreal and Toronto compared. Urban Geography, 28.1, 30-53.

Brenner, N. (2002) Decoding the newest "metropolitan regionalism" in the U.S.A.: A critical overview. Cities, 19.1, 3-21.

Brenner, N. (2004) New state spaces: Urban governance and the rescaling of statehood. Oxford University Press: Oxford.

Brenner, N., D. J. Madden and D. Wachsmuth (2012) Assemblages, actor-networks, and the challenges of critical urban theory. In N. Brenner, P. Marcuse and M. Mayer (eds), Cities for people, not for profit: Critical urban theory and the right to the city (pp. 117-137). Routeledge: New York.

Center for Neighborhood Technology (2010) Chicago Soutbland's Green TIME Zone. CNT: Chicago.

Center for Neighborhood Technology (2012) Prospering in place: Linking jobs, development and transit to spur Chicago's economy. CNT: Chicago.

Chicago Metropolitan Agency for Planning (2010) Go to 2040 plan. CMAP: Chicago.

Cidell, J. (2011) Distribution centers among the rooftops: The global logistics network meets the suburban spatial imaginary. International Journal of Urban and Regional Research, 35.4, 832-51.

Cidell, J. (2012) Fear of a foreign railroad: Transnationalism, trainspace, and (im)mobility in the Chicago suburbs. Transactions of the Institute of British Geographers, 37.4, 593-608.

Citizens Environmental Coalition (2012) Sustainable Vaughan. (available at http://sustainablevaughan.com/; last accessed 9 March 2015).

City of Vaughan (2011) Vaughan vision 2020: The City of V aughan strategic plan. City of Vaughan: Vaughan.

Cox, K. R. (2010) The problem of metropolitan governance and the politics of scale. Regional Studies, 44.2, 215-27.

Cox, K. R. (2013) Territory, scale, and why capitalism matters. Territory, Politics, Governance, 1.1, 4661.

Deas, I. (2014) The search for territorial fixes in subnational governance: City-regions and the disputed emergence of post-political consensus in Manchester, England. Urban Studies, 51.11, 2285-2314.

Dembski, S. (2015) Structure and imagination of changing cities: Manchester, Liverpool and the spatial in-between. Urban Studies, 52.9, 1647-1664.

Drennan, R. (2013) Mississauga Summit wants us to move, live and thrive. (available from http://www.mississauga.com/news/article/1615648--mississauga-summit-wants-us-tomove-live-and-thrive; last accessed 10 May 2013) 
Ekers, M., P. Hamel and R. Keil (2012) Governing suburbia: Modalities and mechanisms of suburban governance. Regional Studies, 46.3, 405-22.

Farias, I. (2010) Introduction: Decentering the object of urban studies. In I. Farias and T. Bender (eds), Urban assemblages: How actor-network theory changes urban research (pp. 1-24). Routledge: New York.

Farias, I. (2011) The politics of urban assemblages. City: Analysis of urban trends, culture, theory, policy, action, 15.3-4, 365-74.

Fishman, R. (1987) Bourgeois utopias: The rise and fall of suburbia. Basic Books: New York.

Florida, R. (2012) What Toronto needs now: Richard Florida offers a manifesto for a new model of leadership (available from http://www.torontolife.com/daily/informer/from-printedition-informer/2012/10/22/what-toronto-needs-now/; last accessed 24 October 2012).

Fong, E., C. Luk and E. Ooka (2005) Spatial distribution of suburban ethnic businesses. Social Science Research, 34.1, 215-35.

Graham, S. and S. Marvin (2001) Splintering urbanism: Networked infrastructures, technological mobilities and the urban condition. Routledge: New York.

Hamel, P. and R. Keil (eds) (2015) Suburban governance: A global view. University of Toronto Press: Toronto.

Harding, A. (2007) Taking city regions seriously? Response to debate on city regions? New geographies of governance, democracy and social reproduction. International Journal of Urban and Regional Research, 31.2, 443-58.

Harvey, D. (1978) The urban process under capitalism: A framework for analysis. International Journal of Urban and Regional Research, 2.1-4, 101-131.

Haughton, G., P. Allmendinger and S. Oosterlynck (2013) Spaces of neoliberal experimentation: Soft spaces, postpolitics, and neoliberal governmentality. Environment and Planning A, 45.1, 217234.

Hulchanski, D. (2010) The three cities within Toronto: Income polarization among Toronto's neighborboods, 1970-2005. University of Toronto Centre for Urban and Community Studies: Toronto.

Ipsos Reid (2012) Commuter Attitudes Survey 2011. Smart Commute, Metrolinx: Toronto.

Johnson, E. W. (2001) Chicago metropolis 2020: The Chicago Plan for the twenty-first century. University of Chicago Press: Chicago.

Jonas, A. E. G. (2011) Post-suburban regionalism: From local politics of exclusion to regional politics of economic development. In N. A. Phelps and F. Wu (eds) International perspectives on suburbanization: A post-suburban world? (pp. 81-100) Palgrave Macmillan: Basingstoke.

Jonas, A. E. G., A. R. Goetz and S. Bhattacharjee (2014) City-regionalism as a politics of collective provision: Regional transport infrastructure in Denver, USA. Urban Studies, 51.11, 2444-2465.

Jonas, A. E. G. and K. G. Ward (2007) Introduction to a debate on city-regions: New geographies of governance, democracy and social reproduction. International Journal of Urban and Regional Research, 31.1, 169-78.

Jones, M. (2009) Phase space: Geography, relational thinking, and beyond. Progress in Human Geography, 33.4, 487-506.

Jones-Correa, M. (2006) Reshaping the American Dream: Immigrants, ethnic minorities and the politics of the new suburbs. In K. M. Kruse and T. J. Sugrue (eds) The new suburban history (pp. 183-204). University of Chicago Press: Chicago.

Keil, R. (2011) Global suburbanization: The challenge of researching cities in the 21st century. Public, 43.1, 54-61.

Keil, R. (ed) (2013) Suburban constellations: Governance, land and infrastructure in the 21st century. Jovis Verlag: Berlin.

Keil, R., P. Hamel, J.-A. Boudreau and S. Kipfer (eds) (forthcoming) Governing cities through regions: Canadian and European perspectives. Wilfred-Laurier University Press: Waterloo. 
Keil, R. and D. Young (2011) Post-suburbia and city-region politics. In N. A. Phelps and F. Wu (eds) International perspectives on suburbanization: A post-suburban world? (pp. 54-78). Palgrave Macmillan: Basingstoke.

Kirkpatrick, L. O. and M. P. Smith (2011) The infrastructural limits to growth: Rethinking the urban growth machine in times of fiscal crisis. International Journal of Urban and Regional Research, 35.5, 477-503.

Kneebone, E., C. Nadeau and A. Berube (2011) The re-emergence of concentrated poverty: Metropolitan trends in the 2000s. Brookings Institute: Washington, DC.

Knowles, F. (2011) Poverty seeping into suburbs. Chicago Sun-Times, 23 October: 6.

Knox, P. L. (2008) Metroburbia, USA. Rutgers University Press: Piscataway.

Lefebvre, H. (2003) The Urban Revolution. University of Minnesota Press: Minneapolis.

Lewis, R. (ed) (2004) The manufacturing suburb: Building work and home on the metropolitan fringe. Temple University Press: Philadelphia.

Lo, L. (2011) Immigrants and social services in the suburbs. In D. Young, P. Wood and R. Keil (eds) In-between infrastructure: Urban connectivity in an age of vulnerability (pp. 131-150). Praxis (e) Press: Keolowna.

Longworth, R. C. (2004) The political city. In C. Madigan (ed) Global Chicago (pp. 70-93). University of Illinois Press: Chicago.

Macdonald, S. and R. Keil (2012) The Ontario greenbelt: shifting the scales of the sustainability fix? The Professional Geographer, 64.2, 125-145.

MacLeod, G. (2011) Urban politics reconsidered: Growth machine to post-democratic city? Urban Studies, 48.12, 2629-60.

Massey, D. (2005) For space. Sage: London.

McCann, E. and Ward, K. G. (eds) (2011) Mobile urbanism: Cities and policymaking in the global age. University of Minnesota Press: Minneapolis.

McFarlane, C. (2011a) Assemblage and critical urbanism. City: Analysis of urban trends, culture, theory, policy, action, 15.2, 204-24.

McFarlane, C. (2011b) On context: Assemblage, political economy and structure. City: Analysis of urban trends, culture, theory, policy, action, 15.3-4, 375-88.

McGuirk, P. (2012) Geographies of urban politics: Pathways, intersections, interventions. Geographical Research, 50.3, 256-68.

Metrolinx (2008) The Big Move: Transforming transportation in the Greater Toronto and Hamilton Area. Metrolinx: Toronto.

Metropolitan Planning Council (2011) Bus rapid transit: Chicago's new route to opportunity. Metropolitan Planning Council: Chicago.

Paasi, A. (2010) Regions are social constructs, but who or what 'constructs' them? Agency in question. Environment and Planning A, 42.10, 2296-2301.

Painter, J. (2010) Rethinking territory. Antipode, 42.5, 1090-1118.

Peck, J. (2011) Neoliberal suburbanism: Frontier space. Urban Geography, 32.6, 884-919.

Peto, J. (2011) Why the Town of Markham is so concerned about Israeli Apartheid Week. The Bullet: Socialist Project E-Bulletin, 7 April (available at http://www.socialistproject.ca/bullet/487.php; last accessed 3 November 2011).

Phelps, N. A. and A. Wood (2011) The new post-suburban politics? Urban Studies, 48.12, 2591 2610.

Phelps, N. A. and F. Wu (eds) (2011) International perspectives on suburbanization: A post-suburban world? Palgrave Macmillan: Basingstoke.

Regional Transportation Authority (2012) Pace bus ridership summary for May 2012. RTA Mapping and Statistics. (available at http://www.rtams.org/rtams/ridershipSummary.jsp?dataset=paceBus; last accessed 2 August 2012). 
Rodgers, S., C. Barnett and A. Cochrane (2014) Where is urban politics? International Journal of Urban and Regional Research, 38.5, 1551-1560.

Rodkin, D. (2011) Census shows Afrcian American leaving high-priced suburbs. Chicago Mag. 27 April. (available at http://www.chicagomag.com/Radar/Deal-Estate/April2011/Census-Shows-African-Americans-Leaving-High-Priced-Suburbs/; last accessed 2 January 2013).

Salet, W., B. Scholl, and R. Vermeulen (2014) Relocating centers of urban activity in the urban periphery? disP: The Planning Review, 50.2, 4-5.

Sassen, S. (2006) Territory, authority, rights: From medieval to global assemblages. Princeton University Press: Princeton.

Savini, F. (2014) What happens to the urban periphery? The political tensions of postindustrial redevelopment in Milan. Urban Affairs Review, 50.2, 180-205..

Schafran, A. (2013) Discourse and dystopia, American style: The rise of 'slumburbia' in a time of crisis. City: Analysis of urban trends, culture, theory, policy, action, 17.2, 130-48.

Schwieterman, J., J. Delumo, C. Khazai, M. Patoska, M. Pelon, L. Santos and M. Schulz (2012) The 20 "top transit suburbs" of metropolitan Chicago. Chaddick Institute for Metropolitan Development, De Paul University: Chicago.

Scott, A. J. (2001) Globalization and the rise of city-regions. European Planning Studies, 9.7, 813-26.

Soja, E. W. (2000) Post-metropolis. Blackwell: Cambridge.

Storper, M. (2013) Keys to the city: How economics, institutions, social interaction, and politics shape development. Princeton University Press: Princeton.

Teaford, J. (1997) Post-suburbia: Government and polities in edge cities. Johns Hopkins University Press: Baltimore.

Teixeira, C. (2008) Residential experiences and the culture of suburbanization: A case study of Portugese homebuyers in Mississauga. Housing Studies, 22.4, 495-521.

Turcotte, M. (2011) Commuting to work: Results of the 2010 General Social Survey. Statistics Canada: Ottawa.

United Way Toronto (2011) Vertical poverty: Poverty by postal code 2. United Way: Toronto.

Wachsmuth, D. (2014) City as ideology: Reconciling the explosion of the city form with the tenacity of the city concept. Environment and Planning D: Space and Society, 31.1 75-90.

Washington, G. (1994) Green line rehab foes in last stand. Chicago Tribune, 6 January, 3.

Walks, R. A. (2013) Suburbanism as a way of life, slight return. Urban Studies, 50.8, 1471-88.

Ward, K. G. and A. E. G. Jonas (2004) Competitive city regionalism as a politics of space: A critical reinterpretation of the 'new regionalism'. Environment and Planning A, 36.12, 211939.

Wills, J. (2008) Mapping class and its political possibilities. Antipode, 40.1, 25-30.

Young, D. and R. Keil (2014) Locating the urban in-between: Tracking the urban politics of infrastructure in Toronto. International Journal of Urban and Regional Research, 38.5, 15891608. 


\section{Figures:}

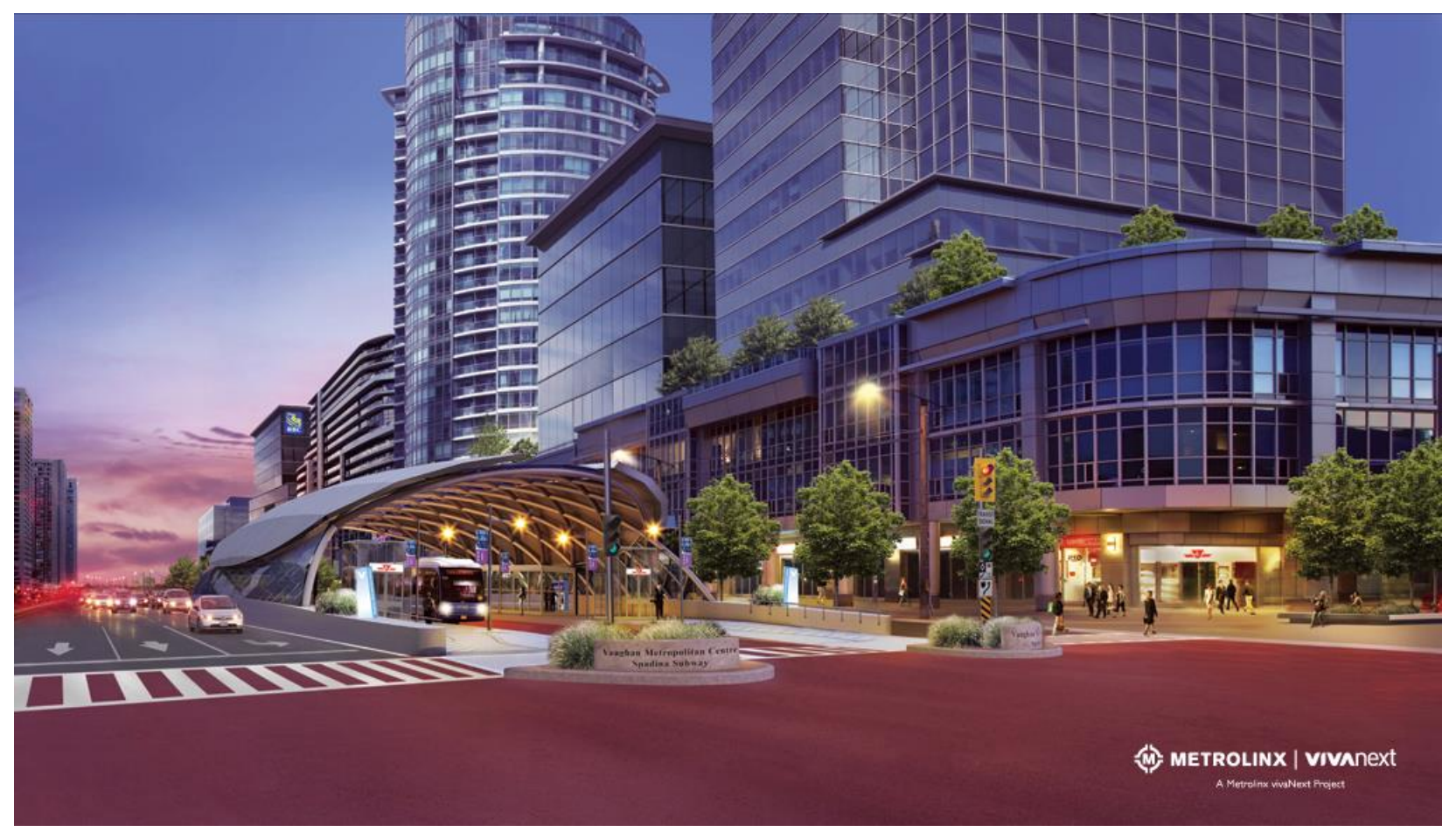

Figure 1: 'Vaughan Metropolitan Centre'. Renderings illustrate the multimodal transportation networks brought together along Highway 7 by the Province of Ontario's mobility hub strategy including Viva BRT and the TTC's Spadina subway extension - as well as the infrastructural splintering engendered through VivaNext's 'rapidways', Source: Copyright, York Region Rapid Transit Corporation (vivaNext). Reproduced with permission. 


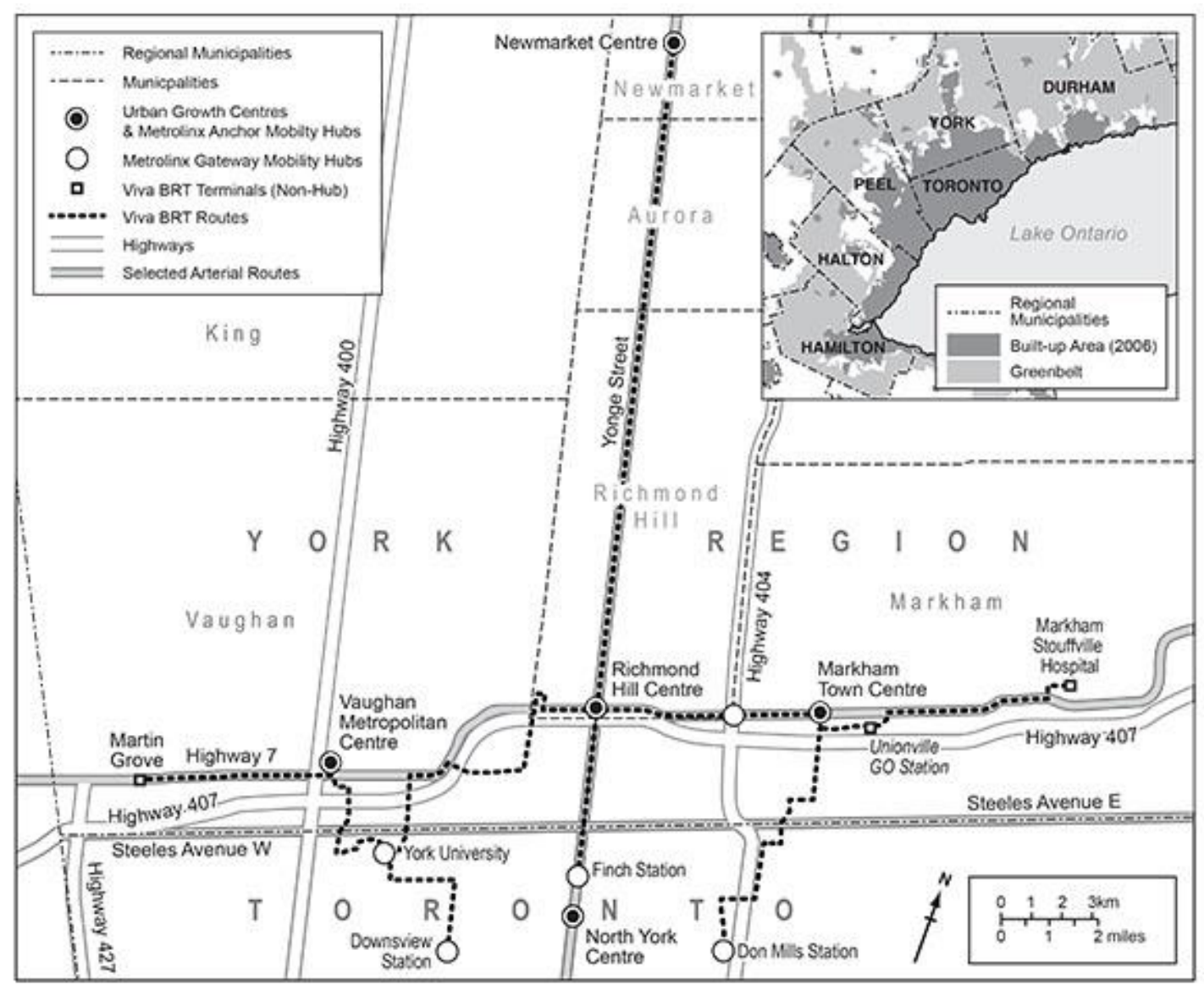

Figure 2: Viva's BRT system and the Province of Ontario's growth hub strategy, as of Fall 2013. Bus rapid transit, anchored along Highway 7 and Yonge Street, provides key technologies to structure on-going post-suburbanization in York Region and (selectively) integrate regional space through terminals in Toronto. Figure by Jean-Paul Addie and Miles Irving, Cartographic Officer, University College London. 


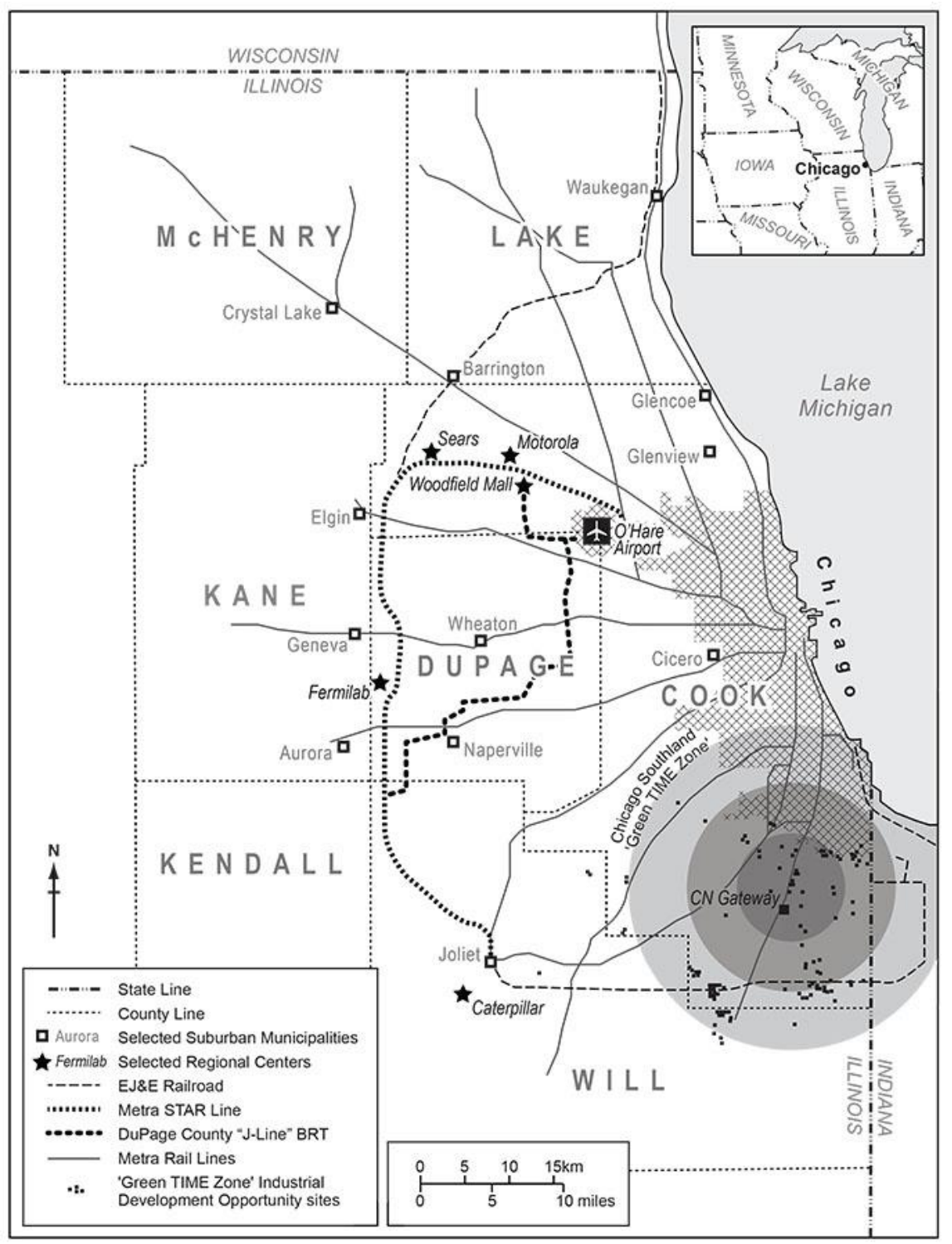

Figure 3: Metra's STAR Line and DuPage County's proposed “J-Line” BRT system. The STAR Line proposal seeks to integrate existing radial rail routes and connecting key suburban growth nodes. The route would provide non-automobile travel options for 1.2 million employees commuting to major suburban institutions, retail centers, and corporate campuses. Also illustrated are the core, inner, and outer rings of the Chicago Southland 'Green TIME Zone'. The proposal to form a sub-regional green manufacturing cluster ties industrial development opportunities to brownfield redevelopment and existing rail, road and intermodal infrastructure (see page 25). Figure by Jean-Paul Addie and Miles Irving, Cartographic Officer, University College London. 